\title{
Economic Factors Undermining National Security: Joint Defence Facility Pine Gap, Australia
}

\author{
M. Beck \\ Peoples' Friendship University of Russia (RUDN University) \\ Miklukho-Maklaya str., 6, Moscow, Russian Federation, 117198
}

\begin{abstract}
The article analyses Joint Defence Facility Pine Gap in Australia that is used by the United States to controls satellites pinpoint airstrikes around the world. The Joint Facility rises political controversy in Australia (especially after Edward Snowden's revelations) as many doubt if it is in Australia's best interests to contribute data for drone assassinations and targeting US nuclear weapons. Considering Australia's policy towards Joint Defence Facility Pine Gap the author raises the question whether national security can be "outsourced" to save budget funds. The article concludes that in Australia it is noticeable that human intelligence potential in financial terms is less valued than some construction, manual jobs. Considering that Russia and China, which are in the focus of Pine Gap intelligence gathering do not outsource its national security and were more successful in preventing major information leaks, moreover in preventing major terrorist attacks on their soil, is indicating that national security should not be privatized.
\end{abstract}

Keywords: national security, Joint Defence Facility Pine Gap, Australia, Edward Snowden, defence budget

\section{Introduction}

Pine Gap is the commonly used name for an Australian Earth station approximately 18 kilometers south-west of the town Alice Springs, Northern Territory in the center of Australia. From the base, the United States controls satellites that gather information used to pinpoint airstrikes around the world and target nuclear weapons, among other military and intelligence task, according to experts and leaked National Security Agency documents [1;2;3]. Born at the height of the Cold War, Pine Gap was presented to the Australian public in 1966 as a space research facility. But behind the scenes, the station was run by the CIA to collect information from American spy satellites about the Soviet Union's missile program. In late 1966, a joint US-Australian treaty called for the creation of the "Joint Defence Space Research Facility" which purpose was initially referred to public as 
"space research". Operations started in 1970 when about 400 American families moved to Central Australia. Since 1988, it has been officially called the "Joint Defence Facility Pine Gap (JDFPG). Partly run by the US Central Intelligence Agency (CIA), US National Security Agency (NSA) and US National Reconnaissance Office (NRO), the station is the key contributor to the NSA's global interception effort, which included the ECHELON program. A long term NSA employee at Pine Gap, David Rosenberg in his book, "Inside Pine Gap: The Spy who Came in from the Desert" from 2011, indicated that the chief of the facility at the time of his service was a CIA officer. The location is strategically significant because it controls United States spy satellites as they pass over one third of the globe which includes China, the Asian parts of Russia and the Middle East. Central Australia was chosen because it was to remote for spy ships passing in international waters to intercept the signal.

In 1999, with the Australian Government refusing to give details to Australian Senate committee on treaties, intelligence expert Professor Des Ball from the Australian National University was called to give an outline of Pine Gap. According to Professor Ball, since 9 December 1966 when Australian and United States governments signed the Pine Gap Treaty the facility had grown from the original two antennas to about eighteen in 1999. The number of staff had increased from around 400 in the early 1980 s to 600 in early 1990's and then to over 1000. The staff at Pine Gap was predominantly American until the 1980's, when the two governments, responding in part to public pressure, made it about half Australian. Today, more than 800 people from both countries are believed to work at the base. But the United States is firmly in control. Since the end of the Cold War, the station has mainly been employed with intercepting and recording weapons and communications signals from countries in Asia, such as China and North Korea. The station was active in supporting the wars in Afghanistan and Iraq after the 9/11 attacks. Interesting fact is that the biggest expansion occurred after the end of the Cold War.

On 11 July 2013, documents revealed through former NSA contractor Edward Snowden, showed that Pine Gap, amongst three other locations in Australia and one in New Zealand, contributed to the NSA's global collection of internet and telephone communications, which involves systems like XKEYCORE. According to other Snowden documents published in August 2017, Pine Gap, together with the NSA's Menwith Hill base in England is used as a ground station and a command post for spy satellites on two different missions: Mission 7600 with 2 geosynchronous satellites which provide continuous coverage of majority of the Eurasian landmass and Africa, this initiative was later upgraded to Mission 8300 with 4 geosynchronous satellites which cover the former Soviet Union, China, South Asia, the Middle East, Eastern Europe and territories in the Atlantic Ocean [4; 5].

Professor Richard Tanter, a Senior Research Associate at the Nautilus Institute for Security and Sustainability and Honorary Professor, School of Social and Political Sciences, the University of Melbourne, he is also the Chair of Australian Board of the International Campaign for the Abolition of Nuclear Weapons (ICAN), which has been awarded the Nobel Peace Prize 2017, said he wanted the government to "make a very clearheaded assessment" of weather it is in Australia's best interest to 
contribute data for drone assassinations and targeting nuclear weapons. Other experts, however, said that hosting a base like Pine Gap helps maintain the country's alliance with the United States, and that other partners of the Americans carry considerably larger burdens. In that hindsight, Stephen Frühling, a professor at the Strategic and Defense Studies Centre of the Australian National University said that the Australians are "not doing a lot of things that our allies are doing", including permanently hosting American nuclear weapons and soldiers.

\section{Results}

Investment in Australian and US human intelligence (HUMINT) capital was in decline in recent years which can be seen from various examples of security breaches. Some examples with disastrous consequences can be seen in the last decade such as in Iran and China. In 2009, Iran apparently infiltrated the communications network of CIA agents, used to exchange messages with informants. Following the Iran disaster in a two-year period starting from the 2010, Chinese officials began accurately identifying spies working for the US, an action which was the result of exact correlation of Iranian and Chinese cooperation and was a clear underestimation of the Chinese counterintelligence capabilities and general sloppiness of the CIA. The whole CIA spying operations in China were systematically dismantled by the Chinese government. Chinese killed or imprisoned 30 of the CIA sources in China. Another breach occurred in 2017, case of Joshua Schulte, a former CIA computer engineer has been indicted on charges he masterminded what appears to be the largest leak of classified information in the agency's history in March 2017. Schulte was the target of a major investigation into WikiLeaks' release of a CIA collection known as "Vault 7".

In regards of intelligence activities, news reports, articles, media releases, government statements have one word in common, a "contractor". In ever changing globalized world where "outsourcing" wiped out numerous jobs, and economically toppled the middle class in numerous western democracies, this economic term has political and security consequences. The key question is, can national security be "outsourced" and can governments save money because they hire outsourced contractors instead of trained and trusted professionals with strong sense of national pride? In comparison with key US adversaries such as Russia and China, it is important to mention that in latter two national security is more a national pride then just business, moreover they are much more successful in dealing with security treats than the security agencies in the US security specter, Australia included. The countries of Five Eyes intelligence agreement Australia, Canada, New Zealand, United Kingdom and the United States have vast and advanced capabilities in terms of signals intelligence (SIGINT) and geospatial intelligence (GEOINT), nevertheless it seems that most information leaks occurred due to the human intelligence (HUMINT). It's up for a debate if the salaries in the intelligence community are up to standards in comparison to other employment opportunities in the civil sector, moreover the usage of services provided by private companies to deal with sensitive materials and issues is even more interrogatory. 
This brings us back to the primary issue of this analysis. US and Australian governments are spending vast sums of financial funds for military equipment, hardware, signals (SIGINT) and geospatial (GEOINT) intelligence, but there are constant debates about the salaries of personnel for instance of Australian Defence Force, which will be taken for account in this analysis do to the availability of information.

In Australia, it is noticeable that human intelligence potential in financial terms is less valued than some construction, manual jobs. According to the Australian Department of Defence and Australian Public Service (APS), a centralized Australian job sites engine, an annual salary of a Security Adviser at the Intelligence, Security and International Policy Division at Pine gap is between 58,009 and 62,135 AUD, salary figures in Australia are in gross amount. Department of Defence also has Intelligence Officer and Intelligence Analyst roles in the Army, Air Force and the Navy where intelligence and analyst roles salary start from 43,000 - 49,000 AUD and after full training go up to 70,000 - 75,000 AUD. Since the job structure in Australia in the last decade made a sharp shift from full time employment towards part time and casual employment a prospect of fulltime employment with the Defence Force can have a good perspective at first sight. There are two major issues with this constellation.

First issue is the fact that Australia has a strong construction sector where some construction jobs for instance FIFO (fly in fly out) jobs are paying significantly more, where entry level salaries are around 80,000 - 100,000 AUD per annum, even some basic construction jobs in major cities would pay same or more then the Defence force and without any serious responsibility involved in comparison with sensitive national security issues and without any requirement for tertiary education degree. Intriguing part is that for some of these construction roles there is no requirement in regards of formal education, certification etc. For jobs like steel-fixing, usual requirement is just 2-3 years of experience and this job precondition is often not verified. Another financial issue is comparison of salaries in defence intelligence and civil intelligence agencies, where the higher salaries are being paid in the civil sector where the Defence force loses staff after providing expensive training to their personnel.

Second major issue with recruitment of defence intelligence personnel is the one of political nature. Australian Defence Force (ADF) was under scrutiny in recent years from human rights advocates and NGO's in regards of transparency, which led to the extremely impersonal recruitment process where a computer system in Canberra makes decisions without the possibility of recruitment officer giving his remarks in regards of physical, mental and educational base of each applicant. These measures has as a result in influx of many unsuitable applicants for certain roles and the fact that ADF loses probably many suitable candidates in the bureaucratic labyrinth of trying not to be accused of violation of human rights and political correctness, hence this can lead to lawsuits. Taking that in favor there is a constant public scrutiny about accepting cultural, sexual and national minorities in the ADF and in this case there is a constant probability that the political incentive prevails in the recruitment of the best candidate. 


\title{
Conclusion
}

Considering that Russia and China, which are in the focus of Pine Gap intelligence gathering do not outsource its national security and were more successful in preventing major information leaks, moreover in preventing major terrorist attacks on their soil, is indicating that national security should not be privatized. Australian government is set to increase the annual defence budget with the 2020/2021 goal of two percent of GDP funding target, that is in real terms an increase from 35 billion AUD to 42,4 billion AUD per annum. Budget increase consist of many item's in terms of hardware and total increase of personnel, it is yet to be seen if the financial income of staff will be boosted and how much of these funds will receive officers dealing with sensitive material. Recent backlash in regard of mentioned cases regarding major leaks and counter-intelligence penetration should be taken in account for future allocation of financial resources, so the disastrous events like WikiLeaks, would be prevented. This can be achieved in bringing back the patriotic aspect in national security as well as assuring that the personnel dealing with sensitive information is not burdened with personal financial issues.

\section{REFERENCES}

[1] Dent J. An American Spy Base Hidden in Australia's Outback. The New York Times. Australia. 23.11.2017. URL: https://www.nytimes.com/2017/11/23/world/australia/pinegap-spy-base-protests.html. Accessed: 10.10.2019.

[2] Rada J. Smart Defence: Joint Geospatial Support in NATO. GeoScape. 2019; 13 (2): 98-105. DOI: https://doi.org/10.2478/geosc-2019-0009

[3] Pine Gap - an introduction. Nautilus Institute for Security and Sustainability. URL: https://nautilus.org/publications/books/australian-forces-abroad/defence-facilities/pinegap/pine-gap-intro/. Accessed: 10.10.2019.

[4] Paganini P. New Snowden Docs Reveal the NSA Spy Hub Pine Gap in Australia. Security Affairs. 21.08.2017. URL: https://securityaffairs.co/wordpress/62202/intelligence/pine-gap-nsa-base.html. Accessed: 10.10.2019.

[5] Edward Snowden's New Leak: The Action of the Pine Gap Base. SecNews. 20.08.2017. URL: https://en.secnews.gr/160303/edward-snowden-pine-gap/. Accessed: 10.10.2019.

Научная статья

\section{Экономические факторы, подрывающие национальную безопасность: пример Совместного оборонного комплекса Пайн-Гэп, Австралия}

\author{
М. Бек \\ Российский университет дружбы народов, \\ ул. Миклухо-Маклая, 6, Москва, Россия, 117198
}

Аннотация. В статье анализируется Совместный оборонный комплекс Пайн-Гэп в Австралии, который используется Соединенными Штатами для управления спутниками. Данный совместный военный объект вызывает политические споры в Австралии 
(особенно после разоблачений Эдварда Сноудена), поскольку многие сомневаются, что в интересах Австралии предоставлять данные для атак беспилотников и наведения ядерного оружия США. Рассматривая политику Австралии в отношении базы Пайн-Гэп, автор поднимает вопрос о том, оправдано ли для экономии бюджетных средств переводить на аутсорсинг объекты, связанные с национальной безопасностью. В статье делается вывод о том, что из-за политики бюджетной экономии в Австралии интеллектуальная работа высококвалифицированного персонала комплекса в финансовом плане часто оплачивается значительно ниже, чем работа сотрудников фирм-подрядчиков: строителей и разнорабочих. В результате наблюдается снижение мотивации сотрудников объекта, что приводит к утечкам секретной информации. Автор высказывает опасения о перспективах приватизации и аутсорсинга объектов национальной безопасности или функций по их обслуживанию.

Ключевые слова: национальная безопасность, Совместный оборонный комплекс Пайн-Гэп, Австралия, Эдвард Сноуден, оборонный бюджет

\section{Информация об авторе:}

Бек Марко - аспирант кафедры сравнительной политологии Российского университета дружбы народов (ORCID ID: 0000-0002-9441-2617) (e-mail: beck.marko@ gmail.com).

\section{Information about the author:}

Beck Marko - PhD Student of the Department of Comparative Politics, Peoples' Friendship University of Russia (RUDN University) (Russian Federation) (ORCID ID: 0000-00029441-2617) (e-mail: beck.marko@gmail.com).

\section{Для цитирования:}

Beck M. Economic Factors Undermining National Security: Joint Defence Facility Pine Gap, Australia // Вестник Российского университета дружбы народов. Серия: Государственное и муниципальное управление. 2020. Т. 7. № 2. С. 135-140. DOI: 10.22363/23128313-2020-7-2-135-140

\section{For citation:}

Beck M. Economic Factors Undermining National Security: Joint Defence Facility Pine Gap, Australia. RUDN Journal of Public Administration. 2020; 7 (2): 135-140. DOI: 10.22363/2312-8313-2020-7-2-135-140 